\title{
RETRACTION
}

\section{Cello scrotum}

It has emerged that this letter by $\mathbf{J}$ Murphy ( $B r$ Med $J$ 1974;2:335) about cello scrotum was a hoax. The author (a non-doctor) and his former wife (a doctor who was involved in writing the letter) confessed to the hoax after the letter was cited in an article published in the BMJ's Christmas issue in 2008.
Their rapid response was posted on bmj.com in December 2008 (http://www.bmj.com/rapid-response/2011/11/02/time-confess).

Cite this as: BMJ 2009;338:b379

๑ BMJ Publishing Group Ltd 2009 